
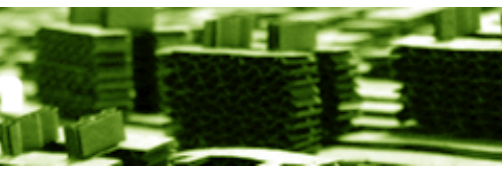

\title{
Proposta integrada de acessibilidade e design de interior: estudo de caso em ambiente de supermercado
}

Proposal for integrating accessibility and interior design: study of case in supermarket environment

\section{MARCO ANTONIO ROSSI}

BRUNA DE BRITO PRADO

JULIANA CAVALINI MARTINS

LAÍS BIM ROMERO

Designer Industrial pela Faculdade de Arquitetura, Artes e Comunicação FAAC-UNESP, mestre em Desenho Industrial pelo Programa de Pós-Graduação em Design da FAACUNESP, doutor em Agronomia pela Faculdade de Ciências Agronômicas FCA-UNESP, professor assistente doutor da FAAC-UNESP.

Graduandas em Arquitetura e Urbanismo da Faculdade de Arquitetura, Artes e Comunicação FAAC-UNESP

mrossi@faac.unesp.br

bb_prado@yahoo.com.br

aucmartins@yahoo.com.br

laisbim@yahoo.com.br

\section{Resumo}

Pessoas com limitações temporárias, dificuldades de locomoção, cadeirantes, crianças e idosos percebem e utilizam os espaços de diferentes maneiras. Para que isso ocorra, devem-se elaborar projetos arquitetônicos associados ao design de interiores, a fim de tornar esses espaços, sejam eles públicos ou privados, acessíveis a todos ou a maior quantidade de usuários possíveis. $\mathrm{O}$ design de interiores representa o contato mais direto entre os usuários e a arquitetura. É através dele que as pessoas interpretam as funções e sensações de determinado ambiente. É aqui que se insere o conceito de desenho universal, responsável por permitir que o usuário utilize os ambientes sem o tratamento discriminatório que a falta de acessibilidade nos edifícios provoca. No design de interiores de supermercado, tema desenvolvido neste artigo, foram aplicados os conceitos de desenho universal com o objetivo de aperfeiçoar o pouco espaço disponível para exposição dos produtos no 
estabelecimento e garantir a acessibilidade dos clientes. Quanto ao projeto arquitetônico, adotaram-se características similares aos armazéns de antigamente, com a aplicação de materiais rústicos. Essa identidade do projeto deu-se devido às preferências do público-alvo encontrado na cidade de Lucianópolis - SP, onde se localiza o supermercado.

Palavras-chave: design de interiores; projeto arquitetônico; desenho universal; acessibilidade.

\begin{abstract}
People with temporary limitations, with locomotion difficulties, wheel chair users, children and senior realize and use the spaces in a different ways. So that occurs, we should elaborate architectural projects associated with interiors design, in order to turn these spaces, public or private, accessible to all or most possible users. The interior of design represents the addressed contact between users and the architecture. It is through it that people interpret the functions and sensations of a determined ambient. It is here that is inserted the concept of universal drawing, responsible for allowing that the user uses the environments without the discriminatory treatment that the accessibility lack buildings provoke. In the supermarket interiors design, developed subject in this article, were applied the concepts of universal drawing with the goal of optimizing the little available space for exhibition of the products in the establishment and to guarantee clients' accessibility. Regarding the architectural project, it adopted similar characteristics to warehouses of formerly, with the application of rustic materials. This identity of the project it's given due to the public-target's preferences met in the city of Lucianópolis SP, where the supermarket is located.
\end{abstract}

Keywords:: interior design; architectural project; universal drawing; accessibility 

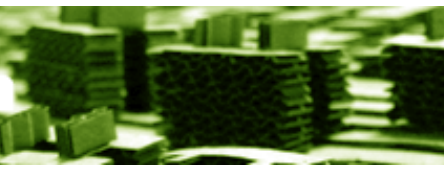

\section{Análise de ambientes concebidos como proposta de acessibilidade e design de interior: estudo de caso em ambiente de supermercado}

\section{Introdução}

Na década de 60, começam a ser discutidos, por estudiosos das áreas afins, desenhos de equipamentos e edifícios direcionados a pessoas com deficiência ou mobilidade reduzida. Posteriormente, este conceito foi denominado desenho universal. O objetivo proposto foi buscar maneiras de reduzir as barreiras arquitetônicas enfrentadas por pessoas com deficiência física. Com esse intuito, profissionais ligados à área, governos e sociedade têm se esforçado para tornar os ambientes construídos acessíveis à diversidade que caracteriza e define o ser humano. A questão da edificação padrão vem instigando há muitos séculos os arquitetos, começando por Vitrúvio' até Le Corbusierii no século XX. Porém, se a arquitetura se atentar apenas ao homem modularmente exemplar, acabará por excluir usuários potenciais, como: crianças, adultos, idosos, cadeirantes, usuários de muletas, altos, baixos, cegos, grávidas, entre outros. Assim sendo, conforme Ornstein (2007) existe uma "relação de mão dupla entre pessoas e ambientes, cujos estudos são importantes para a diversidade humana e a arquitetura para abrigá-la".

O conceito de acessibilidade surgiu na área de arquitetura, nos ideais de projetos livres de barreiras e do desenho universal, trazendo benefícios para deficientes físicos. A Associação Brasileira de Normas Técnicas (ABNT) define o desenho universal como sendo: "[...] aquele que visa atender a maior gama de variações possíveis das características antropométricas e sensoriais da população". Este conceito vem evoluindo desde então e hoje está sendo amplamente difundido, sendo um item obrigatório quando o tema é a acessibilidade. O desenho universal não vê a acessibilidade como um anexo, mas entende que o desenho do meio é capaz de torná-lo mais eficiente, produtivo, confortável, legível e seguro, em graus equivalentes a todas as pessoas. O desenho universal vai além deste pensamento de eliminação de barreiras ou impedimentos físicos, contribui para evitar a necessidade de produção de ambientes ou elementos especiais para atenderem públicos diferentes. É um conceito utilizado na produção de objetos e espaços que buscam contemplar respectivas utilizações por quaisquer pessoas, de forma completa, segura e irrestrita.

Neste sentido, foi proposto um trabalho, desenvolvido por uma turma de estudantes de Arquitetura e Urbanismo, na disciplina anual com 90 créditos, denominada Linguagem 
Arquitetônica II, da Faculdade de Arquitetura, Artes e Comunicação - UNESP, Bauru - SP, com intuito de beneficiar a acessibilidade, para pessoas com dificuldades de locomoção, em edifícios comerciais.

A proposta do trabalho foi analisar projetos comerciais construídos e em usabilidade com o objetivo de elencar problemas, discussões e soluções de adaptações nas configurações projetuais arquitetônicas e através dessa análise, criar um novo projeto que promovesse o bem-estar de um maior número de pessoas, para que usufruíssem dos ambientes concebidos, sempre que possível, com segurança e sem esforços desnecessários. Para a elaboração do projeto, foi necessário aplicar alguns tópicos desenvolvidos anteriormente na disciplina, tais como: desenho técnico através de plantas de edificações, elevações em cortes e em fachadas, projeto de layout, uso da Gestalt ${ }^{\text {iii }}$ na elaboração do design e a aplicação dos conceitos de desenho universal nos projetos elaborados.

Perracini (s.n. apud PRADO, s.n., p. 1) afirma que "os ambientes devem ser planejados para promover e encorajar a independência e a autonomia, de forma que uma boa qualidade de vida possa ser proporcionada a todos os indivíduos". Portanto, o design de interiores é responsável pela identidade da edificação, principalmente em edifícios comerciais, cujo objetivo é valorizá-lo.

Frente às dificuldades encontradas quanto à autorização dos proprietários dos estabelecimentos comerciais, na cidade de Bauru, para a realização desse projeto, o grupo optou por buscar um espaço em uma cidade com menor número de habitantes, o que provavelmente facilitaria o acesso aos estabelecimentos. Dessa forma, escolheu-se o supermercado Armazém, localizado na avenida principal da cidade de Lucianópolis, Estado de São Paulo. O estabelecimento possui área construída de $200 \mathrm{~m}^{2}$, e atende comercialmente uma população, de aproximadamente 2.200 habitantes.

Através da análise do estabelecimento observou-se que o espaço disponível para o desenvolvimento do projeto dificultaria, porém, não impediria a aplicação dos conceitos de acessibilidade e desenho universal, tornando este trabalho um grande desafio para o grupo.

\section{Revisão da Literatura}

\subsection{Design de Interiores}

O design de interior é a arte de combinar formas, linhas, elementos, texturas e cores com criatividade, visando sempre à funcionalidade, qualidade, satisfação do usuário e a 
capacidade de atender as necessidades objetivas e subjetivas do mesmo. Segundo Gurgel (2005), "A arquitetura de interiores deve criar ambientes onde a forma e a função, ou seja, a estética e a funcionalidade, convivam em perfeita harmonia e cujo projeto final seja o reflexo das aspirações de cada indivíduo".

Basicamente, o design divide-se em duas áreas, residencial e comercial, sendo o design de interiores para áreas comerciais o tema discutido ao longo deste artigo.

Para Gurgel (2005), o projeto de design comercial é tido como mais complexo, uma vez que atenderá diferentes pessoas, desde trabalhadores fixos até visitantes esporádicos com necessidades distintas, por isso torna-se necessária a observação da estrutura de trabalho e da imagem da empresa, seus valores culturais, sociais, econômicos e principalmente sua relação com funcionários e público-alvo.

Mancuso (2008) explica que entre os séculos XIX e XX, a arquitetura de interiores era irrelevante, principalmente em ambientes comerciais, pois eram os proprietários que decoravam seus estabelecimentos ou transformavam uma casa em edifício comercial com a simples abertura de uma parede.

Com a globalização, valores como atendimento, conveniência, inovação e imagem relacionada ao produto e a empresa, tornaram-se primordiais para o público consumidor, assim, o projeto de layout pode representar o sucesso de uma empresa, ou deturpar sua imagem e espantar seus consumidores quando mal elaborado. Além disso, também é capaz de selecionar de forma indireta seus consumidores (GURGEL, 2005).

Portanto, fica claro que a arquitetura de interiores desempenha papel importante na empresa. Quer facilitando, quer viabilizando o contato correto e freqüente de seus funcionários quer selecionando clientela quer reafirmando uma marca. (GURGEL, 2005, p. 15b).

Alguns empresários ainda não se deram conta da necessidade de transmitir, no espaço comercial, as características da empresa, como, por exemplo, organização, eficiência, coerência, etc. A culpa, entretanto, não deve ficar restrita aos proprietários, mas também deve ser imputada aos profissionais da criação, que muitas vezes falham na execução de um projeto coerente e funcional, [...], por não identificarem um objetivo global de projeto que vá alem da estética. (GURGEL, 2005, p. 158b).

É imprescindível a pesquisa de materiais, relações interpessoais e o organograma empresarial, obtendo todos os requisitos para a elaboração de um projeto adequado, "[...] que reflita a imagem da empresa, que seja funcional e que atinja suas metas visuais e de conforto" (GURGEL, 2005, p. 18b). 


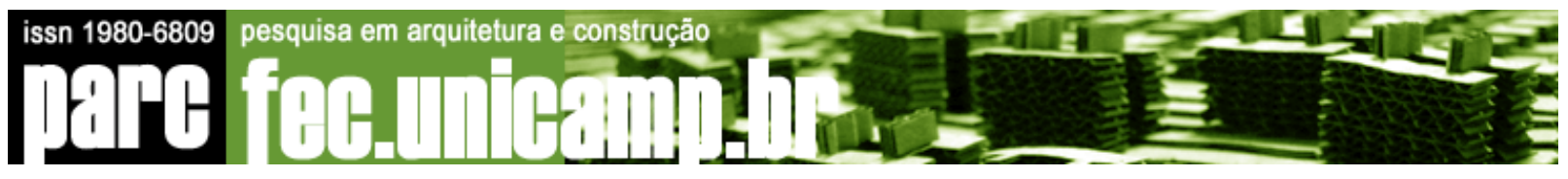

Segundo Gurgel (2005), o espaço de trabalho deve ser eficiente, agradável e promover o bem estar de seus ocupantes, assim iluminação, conforto, ventilação, cores e texturas agradáveis são imprescindíveis e devem ser exploradas. Tendo em vista que cada pessoa tem uma percepção distinta do espaço e que um projeto comercial visa vários beneficiados, algumas vezes torna-se conveniente e necessária a sobreposição da imagem da empresa às necessidades individuais.

É fundamental que a acessibilidade e a circulação nesses espaços atendam a todas as pessoas, independente da idade ou estado físico.

Gurgel (2005) ressalta que a Lei $\mathrm{n}^{\circ} 11.345 / 93$ e a Norma Técnica Brasileira NBR 9050/2004 asseguram a construção ou reforma de edifícios comerciais considerando as pessoas com necessidades especiais. Além dos deficientes físicos, devemos ter a preocupação com a utilização dos espaços destinados aos idosos e às crianças, para isso Gurgel (2005) pontua itens que devem ser evitados ou utilizados, no projeto de interiores:

- Evite desníveis quando desnecessários, ou sinalize os inevitáveis;

- Prefira cantos arredondados no mobiliário;

- Instale barras de segurança onde achar conveniente;

- Instale acendimento por sensor onde convier;

- Instale campainhas nos banheiros de consultórios;

- Proteja tomadas baixas contra o acesso de crianças;

- Projete, sempre que possível, um espaço com livros ou brinquedos para crianças; assim elas ficarão concentradas num mesmo local e se manterão ocupadas, evitando tocar em mercadorias ou fazer barulho;

- Em recepções ou em empresas onde as pessoas devem caminhar por uma longa distância entre setores, proporcione um "local de parada" para repouso, caso venha a ser necessário;

- Sinalize portas e divisórias de vidro.

Para Cambiaghi (2007), uma das primeiras fases de desenvolvimento de um projeto é estabelecer um programa de necessidades, ou seja, um conjunto sistematizado dos usos de uma construção. É nesse momento que se deve considerar a abordagem interdisciplinar de profissionais na área de planejamento e construção, tais como: arquitetos, engenheiros, designers, com visão especifica de cada um deles, buscando resultados satisfatórios para os mais diferenciados usuários. Assim, leva-se também em conta o impacto físico e psicológico causado pelo ambiente, bem como satisfação e segurança; pois "todas as pessoas terão 
problemas com o ambiente quando não forem respeitadas as suas diferenças, dificuldades e características funcionais" (CAMBIAGHI, 2007, p. 45).

Para Mancuso (2008), considerando que um programa comercial pode ter muitas variáveis, abrangendo uma gama de opções e uso, o programa de necessidades é indispensável e pode ser adquirido através de alguns questionamentos como os apresentados a seguir:

- Tipo de comércio: o que exatamente será vendido;

- Número de funcionários no local;

- Faixa etária e sexo do público atendido;

- Localização do estabelecimento comercial;

- Classe social que tem por objetivo atingir;

- Questionar dimensões;

- Fluxo de pessoas no espaço projetado durante o horário de atendimento: O fluxo de pessoas dentro de um ambiente comercial é de extrema importância. Os acessos devem ser muito bem marcados e dependendo do tamanho do ambiente comercial devemos trabalhar com uma sinalização específica.

Assim, conforme Mancuso (2008), como o projeto de caráter residencial deve ser precedido dos anteprojetos, o trabalho na área comercial segue o mesmo critério.

A importância do design, na atualidade, torna-se evidente quando percebemos que o design aplicado a qualquer elemento afeta não somente os objetos que interagem com ele e as pessoas que o utilizam, mas, mais abrangentemente ainda, afeta nosso meio ambiente. (GURGEL, 2005, p. 23c).

\subsection{Desenho Universal}

Quanto mais um ambiente se ajusta às necessidades do usuário, mais confortável ele é. Todavia, se ocorre o inverso, quando o ambiente construído não leva em conta as necessidades ou limitações humanas, ele pode chegar a ser mais inóspito que o meio natural. (CAMBIAGHI, 2007, p.15).

Paula \& Bueno (s.n.) comentam que, assim como todos os fenômenos sociais, a questão da acessibilidade, uma das mais antigas e notáveis reivindicações dos deficientes físicos ou pessoas com mobilidade reduzida, sofreu alterações ao longo da historia, possibilitando um entendimento maior do que é acessibilidade hoje.

Paula \& Bueno (s.n.) discorrem que os primeiros movimentos ocorreram no âmbito da abertura política do início dos anos 80, e visavam à eliminação de barreiras arquitetônicas, 
particularmente nas edificações. Em meados dessa mesma década, esse conceito ampliouse para além das edificações, quando se identificava barreiras ambientais. No início da década de 90, novas barreiras como, deficiência de comunicação e transporte são identificadas, o que possibilita a contemplação de outras deficiências. É valido salientar que neste período, as deficiências eram estudadas de maneira isolada, o que propunha para cada tipo de necessidade uma solução especifica. O conceito de desenho universal surge em meados de 1990, buscando respeitar as características individuais de cada pessoa, sofrendo um grande avanço no terceiro milênio quando o conceito de acessibilidade expande-se e passa a abordar novos aspectos como o direito de ingresso, permanência e usufruto de todos os bens e serviços sociais, construindo uma sociedade que reconhece, respeita e responde às necessidades de todos, ou seja, uma sociedade inclusiva.

As novas tecnologias e a crescente especulação imobiliária provocaram um distanciamento entre os produtos e as reais necessidades do ser humano. Assim, este tem que fazer um esforço para se adaptar a um ambiente projetado para o homem ideal que na maioria das vezes é reflexo dos interesses econômicos que só o vê como consumidor. Notase, portanto, que quanto mais distante se está desse consumidor ideal, mais difícil é a interação entre ele e o ambiente.

Quando crianças não podem utilizar o espaço viário sem a assistência de adultos, por não conseguir identificar e evitar situações perigosas; quando idosos, perdemos parte da nossa mobilidade e da nossa capacidade de visão e audição. Em qualquer momento, essas restrições aplicam-se a aproximadamente um terço da população de muitos países, inclusive o Brasil, que tem uma população relativamente jovem e simultaneamente, uma crescente porcentagem de idosos. (WRIGHT, 2001, p. 3)

Como pais, consumidores, estudantes e trabalhadores, perderam agilidade quando carregamos crianças pequenas, compras, livros, pastas ou ferramentas, ou quando empurramos um carrinho de bebê, de compras ou de mão. As gestantes têm mobilidade reduzida nos últimos meses de gravidez [...] uma perna quebrada ou uma cirurgia poderá confinar-nos temporariamente a uma cadeira de rodas. (WRIGHT, 2001, p. 3)

No ano de 1963, nasce uma Comissão, na cidade de Washington (USA), a Barrier Free Design, com o objetivo de discutir desenhos e projetos arquitetônicos e buscando a redução das barreiras arquitetônicas para pessoas com deficiência física. Foi criado então o conceito de desenho, voltado para equipamentos utilizados por pessoas que apresentassem mobilidade reduzida, evoluindo, a posterior, para o conceito de desenho universal (veja $<$ http://www.rit.edu/ easi/workshops/easiweb.htm>). 
Para Cambiaghi (2007), o desenho universal pode se destinar a qualquer pessoa, por ser fundamental para tornar possível a realização das ações essenciais praticadas na vida cotidiana, o que na verdade é uma consolidação dos pressupostos dos direitos humanos.

Em vista disso, o papel dos profissionais voltados à área de planejamento, projeto, e execução do ambiente construído é fundamental para garantir a qualidade de vida do ser humano, criando ambientes e produtos mais democráticos.

\subsection{Inclusão e Exclusão Social}

Quando uma pessoa com deficiência está em um ambiente acessível, suas atividades são preservadas, e a deficiência não afeta suas funções. Em uma situação contrária, alguém sem qualquer deficiência colocada em ambiente hostil e inacessível pode ser considerado deficiente para esse espaço. (CAMBIAGHI, 2007, p.23).

Foi na década de 70, com a promulgação da Declaração dos Direitos das Pessoas Deficientes (veja <http://portal.mec.gov.br/seesp/arquivos/pdf/dec def.pdf>), que ocorreu um avanço para o início da inclusão de pessoas com deficiência na sociedade. O termo "pessoa deficiente" aborda todas as pessoas impossibilitadas de cumprir sem ajuda, total ou parcial, as exigências de uma vida normal individual e social. Em 2001, foi aprovada pela Assembléia Mundial da Saúde (veja< http://search.vatican.va/roman curia/secretariat state/2003.html>) a inclusão de conceitos voltados para o ambiente em que o deficiente se situa, medindo, portanto, a qualidade de vida dessas pessoas e verificando os fatores ambientais a que estão sujeitas.

A idéia da inclusão, de acordo com Aranha (2000), fundamenta-se numa filosofia que reconhece e aceita a diversidade, na vida em sociedade, garantindo o acesso de todos, a todas as oportunidades, independentemente das peculiaridades de cada indivíduo e/ou grupo social.

No entanto, é preciso ressaltar que "a inclusão é um processo muito mais amplo e diz respeito a uma mudança de olhar sobre o mundo, sobre as relações, sobre os direitos; a inclusão diz respeito à percepção interna de cada indivíduo onde a diversidade passa a ser vista como valor". (CAMBIAGHI, 2007, p.33 e 34).

A sociedade e a pessoa com deficiência se modificam, de forma a conviverem em condições de igualdade e oportunidade, por isso, a inclusão é uma via de mão dupla. Diferente da inclusão é o conceito de integração, que tem como fundamento tornar a pessoa com deficiência apta a conviver em uma sociedade já pronta e organizada para o convívio 
das pessoas sem deficiência, ou seja, a integração fundamenta-se no conceito de incapacidade, pois foca aspectos relacionados às limitações geradas pelas deficiências; sendo, portanto, uma via de mão única, onde a pessoa com deficiência deve se adaptar às situações já estabelecidas àquilo que é considerado normal para a média padrão.

Segundo Cambiaghi (2007), a diferenciação entre inclusão e integração impõe-se no desenvolvimento de projetos de arquitetura e design, onde é preciso encontrar soluções a fim de atender às necessidades específicas de alguns tipos de deficiências como construções de banheiros com dimensões maiores que os demais, instalação de barras de apoio, etc.

Sob uma perspectiva social, integração e inclusão são processos advindos do recíproco que unificam e harmonizam partes diferenciadas.

A Comissão Permanente de Acessibilidade da Secretaria Especial da Pessoa com Deficiência e Mobilidade Reduzida da Cidade de São Paulo (2005) cita que os principais obstáculos encontrados em edificações acontecem em áreas de acessos, circulação horizontal e vertical, aberturas (portas e janelas), sanitários, vestiários, piscinas e mobiliários (telefones, balcões, bebedouros, etc.)

Assim, a acessibilidade aos ambientes construídos e à área urbana é atributo imprescindível à sociedade, que planeja que todos possam desfrutar das mesmas oportunidades. Não podemos esquecer que a diversidade nos caracteriza como espécie.

Quanto mais os projetos forem pensados para atender às necessidades funcionais do maior número possível de pessoas, mais o design e a arquitetura inclusivos serão praticados. Porém, para desenvolver uma arquitetura ou um design inclusivo, é necessário identificar as possíveis necessidades e dificuldades de uso. Eason (1988 apud CAMBIAGHI, 2007, p. 42) diz que esse uso "implica o usuário ser capaz de controlar e utilizar um sistema sem constrangimento sobre suas capacidades e possibilidades".

As leis e normas específicas para deficientes físicos programaram alguns ajustes arquitetônicos tornando locais públicos parcialmente acessíveis através de instalações de rampas, elevadores e banheiros amplos. Contudo, na maioria das vezes, esses acessos não fazem parte da arquitetura como um todo e acabam determinando caminhos e ambientes separados. Esse tem sido o problema de utilizar as normas técnicas sem integrar o conceito de desenho universal. Dessa forma, em lugar de eliminar, acaba-se reforçando o sentimento de exclusão. 


\subsection{Princípios Básicos da Arquitetura Inclusiva}

De acordo com Cambiaghi (2007), para obter ambientes e produtos adaptados à capacidade e às necessidades dos usuários, devem-se adotar, durante a elaboração do projeto, os seguintes critérios:

- Facilitar para todos e sempre o uso do ambiente ou dos produtos a serem projetados;

- Contar com uma amostra representativa de usuários em potencial como participantes dos processos de elaboração do projeto de avaliação;

Com base nesses critérios, o arquiteto ou o estudante de arquitetura deve adaptar seu método de trabalho sem se esquecer que, na maioria dos ambientes construídos, o usuário pode: ser homem, mulher, criança, ter qualquer idade, altura ou peso; ter visão reduzida ou ser cego; capacidade de audição e fala alterada; capacidade de compreensão, memória ou linguagem limitada, ter reflexos lentos, dificuldades para sentar-se e levantar, não ter mãos ou apenas uma delas, usar próteses, órteses ou ajudas técnicas; dificuldade para andar, usar muletas, bengalas, andadores, cadeira de rodas, entre outros, como ilustra a FIG. 1 abaixo.

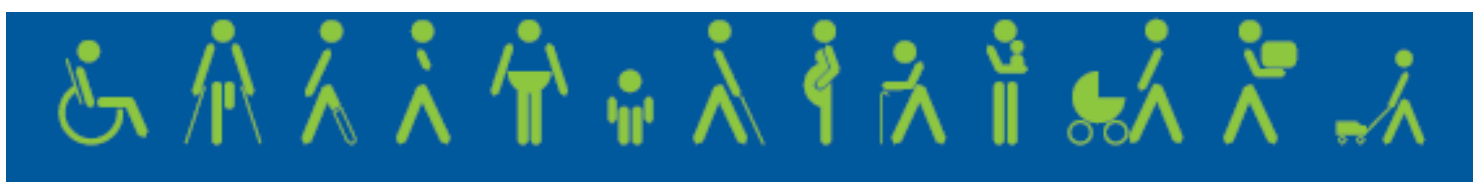

FIGURA 1: Tipos de Limitações.

Fonte: Secretaria de Estado da habitação e Secretaria de Estado dos Direitos da Pessoa com Deficiência. Governo do Estado de São Paulo.

Dessa forma, "o arquiteto, o urbanista, e o designer devem se esforçar permanentemente para não se basearem em si mesmos como usuários potenciais". (CAMBIAGHI, 2007, p. 57).

Conseqüentemente, o desenho universal nada mais é do que uma garantia de que o usuário poderá desfrutar dos ambientes sem receber um tratamento discriminatório por causa de suas características físicas, ou seja, o objetivo é reduzir a distância funcional entre os elementos do espaço e as capacidades das pessoas, enfatiza Cambiaghi (2007).

\section{Discussões e Métodos}

O projeto de interiores em área comercial apresentado a seguir é resultado do trabalho final da disciplina de Linguagem Arquitetônica II, ministrada pelo professor autor deste 
trabalho, a qual pertence ao curso de Arquitetura e Urbanismo da Universidade Estadual Paulista - UNESP - Campus de Bauru. A proposta inicial era apresentar um projeto de layout de um estabelecimento comercial com atendimento ao público, cujo objetivo principal seria a utilização do apelo visual, ou seja, deveria ser compreendido sem explicação oral. O grupo composto pelas outras autoras deste artigo escolheu um supermercado para a realização do trabalho, enquanto que outros grupos escolheram estabelecimentos comerciais de outros segmentos.

Para compreender a diferença entre os conceitos de hipermercado e supermercado Rojo (1998 apud MORO, 2007) explica:

Supermercados são lojas com o método de auto-serviço no varejo de alimentos. Os produtos oferecidos pelo supermercado incluem uma ampla variedade de produtos como: Mercearia, Carnes frescas, Hortifrutícolas, Frios, Lacticínios e não alimentos básicos (perfumaria e limpeza), e Hipermercados são lojas que, além dos produtos alimentícios em autoserviço, oferece uma ampla variedade de não alimentos da linha hard (ex.: eletroeletrônicos, cine - foto - som, utensílios domésticos, etc.), e da linha soft (ex.: confecções, cama, mesa, banho). (MORO, 2007).

Já Alves (s.n.) diferencia os termos de acordo com a dimensão do estabelecimento:

Hipermercados são caracterizados por grandes áreas horizontais, com seções de vendas a partir de $8.000 \mathrm{~m}^{2}$, podendo atingir muitas vezes área superior a $20.000 \mathrm{~m}^{2}$. Estes estabelecimentos seguem o conceito de one stop shopping ("única parada para compras") visando atender a maioria das necessidades de compra com cobertura de todos os tipos de produto (em torno de 50.000 itens), desde os de consumo não duráveis, os semiduráveis e duráveis. Supermercados são lojas com áreas que variam de $100 \mathrm{~m}^{2}$ até cerca de $5.000 \mathrm{~m}^{2}$ e que possuem produtos na maioria do gênero alimentício, em geral, nos ramos de mercearia, carnes, frios, laticínios e hortifrutigranjeiros, trabalhando em média com 20.000 itens. Estes estabelecimentos também oferecem alguns artigos de uso e consumo doméstico imediato, operando pelo sistema de auto-serviço. (ALVES, s.n.).

Tendo como base as definições mencionadas, o mercado Armazém será incluído no ramo de supermercados, devido à sua área, no entanto, vale ressaltar, que o estabelecimento também oferece aos clientes artigos eletroeletrônicos e utensílios domésticos como nos hipermercados.

O desenvolvimento do projeto iniciou-se com um levantamento de dados através de fotos e medições "in loco". Posteriormente foram realizadas pesquisas bibliográficas e de opinião pública, além de considerar os interesses do proprietário em relação ao design a ser adotado em benefício da imagem do estabelecimento. A análise desses dados foi fundamental para a definição do partido arquitetônico adotado no projeto - um armazém; 
tendo como resultado o desenvolvimento projetual de design de interiores em áreas comerciais com propostas de acessibilidade, através de softwares como AutoCAD versão 2008 e Sketch Up Pró 7, ilustrados na FIG. 2.

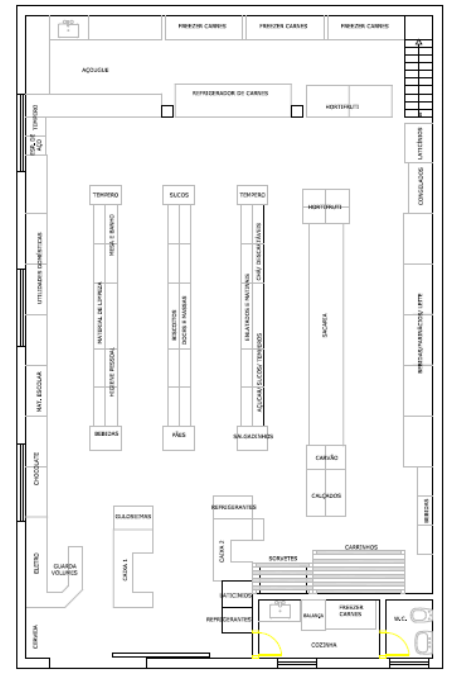

A

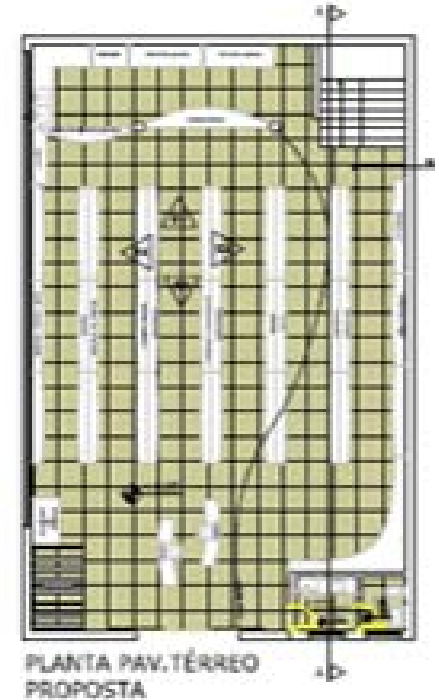

B

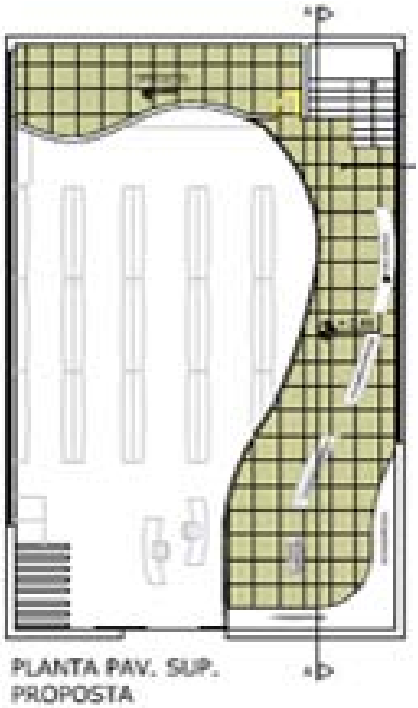

C

FIGURA 2: Planta original (A) e plantas do pavimento térreo (B) e superior do projeto de design de interiores $(\mathrm{C})$

Lucianópolis, onde se localiza o supermercado analisado, é uma cidade com poucos habitantes que fica no interior do Estado de São Paulo. De acordo com o público-alvo encontrado no município, decidimos não realizar um projeto de design de interior muito rebuscado e complexo, pois segundo Gurgel (2005), "o projeto de layout pode [...] selecionar de forma indireta seus consumidores". Por este motivo, tomou-se por base o perfil dos antigos armazéns, onde o principal material adotado era a madeira. Dessa forma, optou-se pelo uso do mesmo material criando um aspecto mais simples aos ambientes, além do emprego de tintas com cores acolhedoras e aconchegantes como tons de marrom, vermelho queimado e laranja-escuro. Veja na FIG. 3A a fachada original; a proposta para o novo projeto na FIG. 3B e na FIG. 4 o detalhamento do projeto de mobiliários, propostos com materiais como madeira e vidro: 


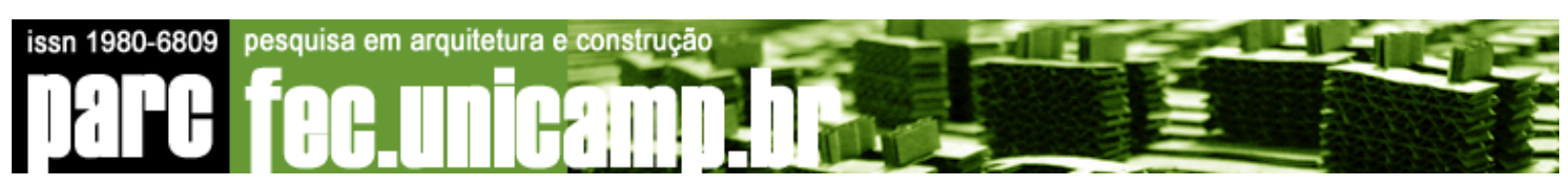

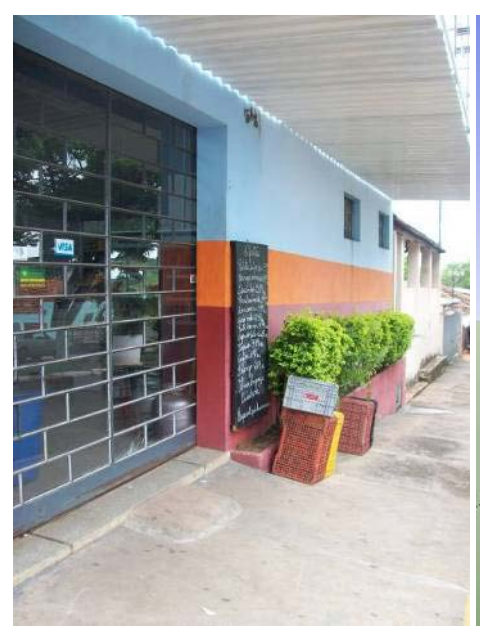

A

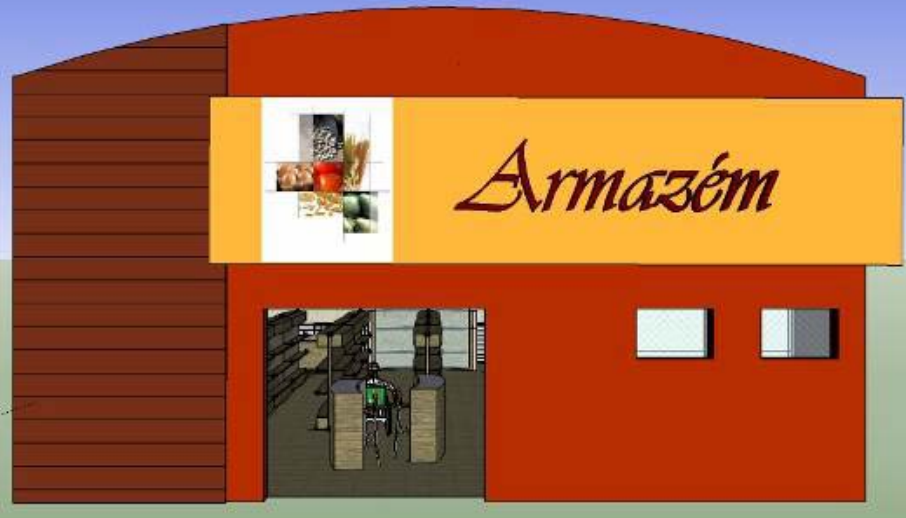

B

FIGURA 3: Fachada original (A) e proposta (B)
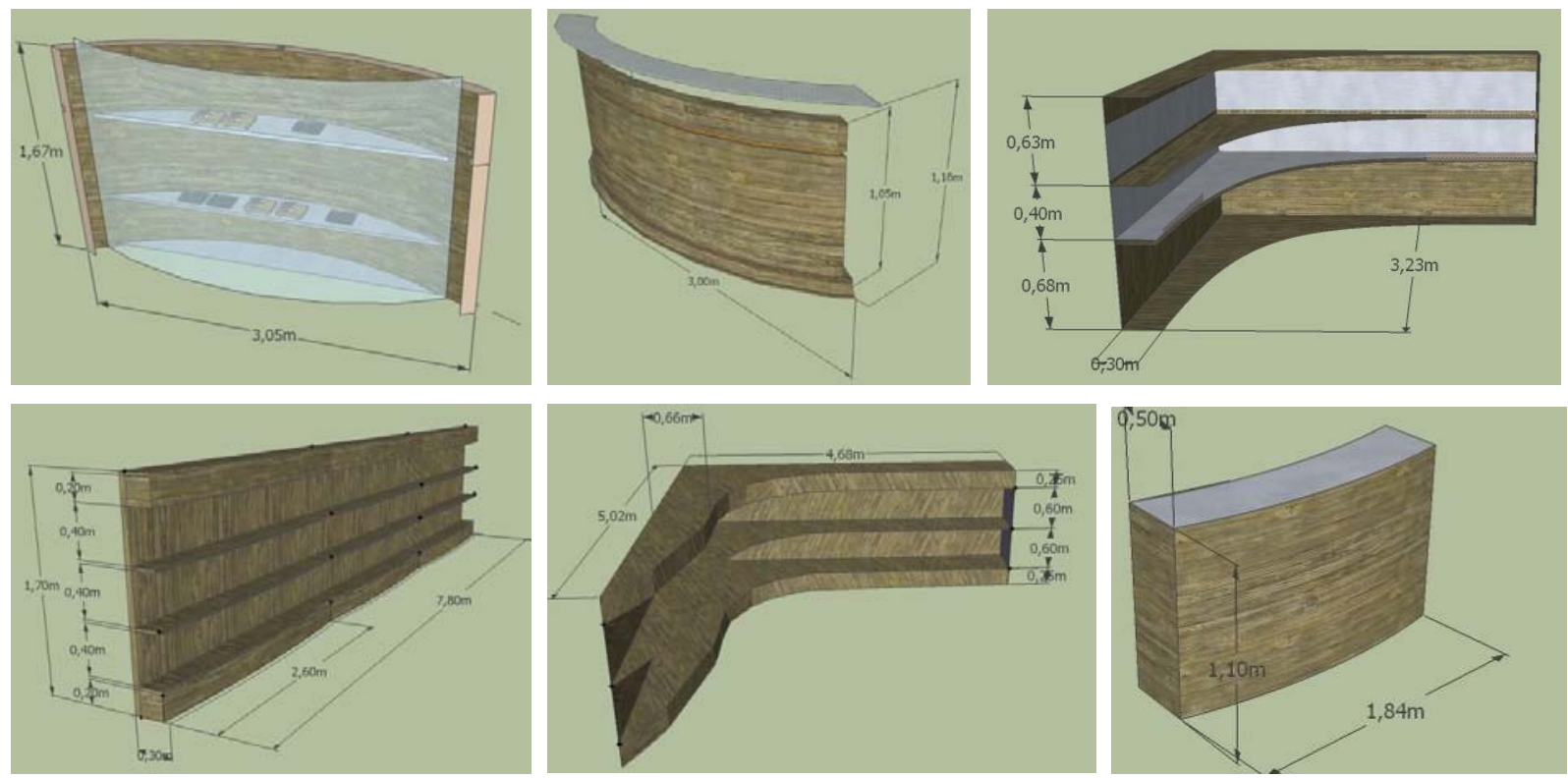

FIGURA 4: Detalhamento dos mobiliários

Gurgel (2005) salienta que o design de interiores deve abrigar forma e função em harmonia. Por isso, as gôndolas e o mezanino do Armazém, em forma sinuosa, foram projetados de acordo com a linguagem arquitetônica proposta, reforçando a característica do projeto, como mostras as FIG. 5 e 6. 

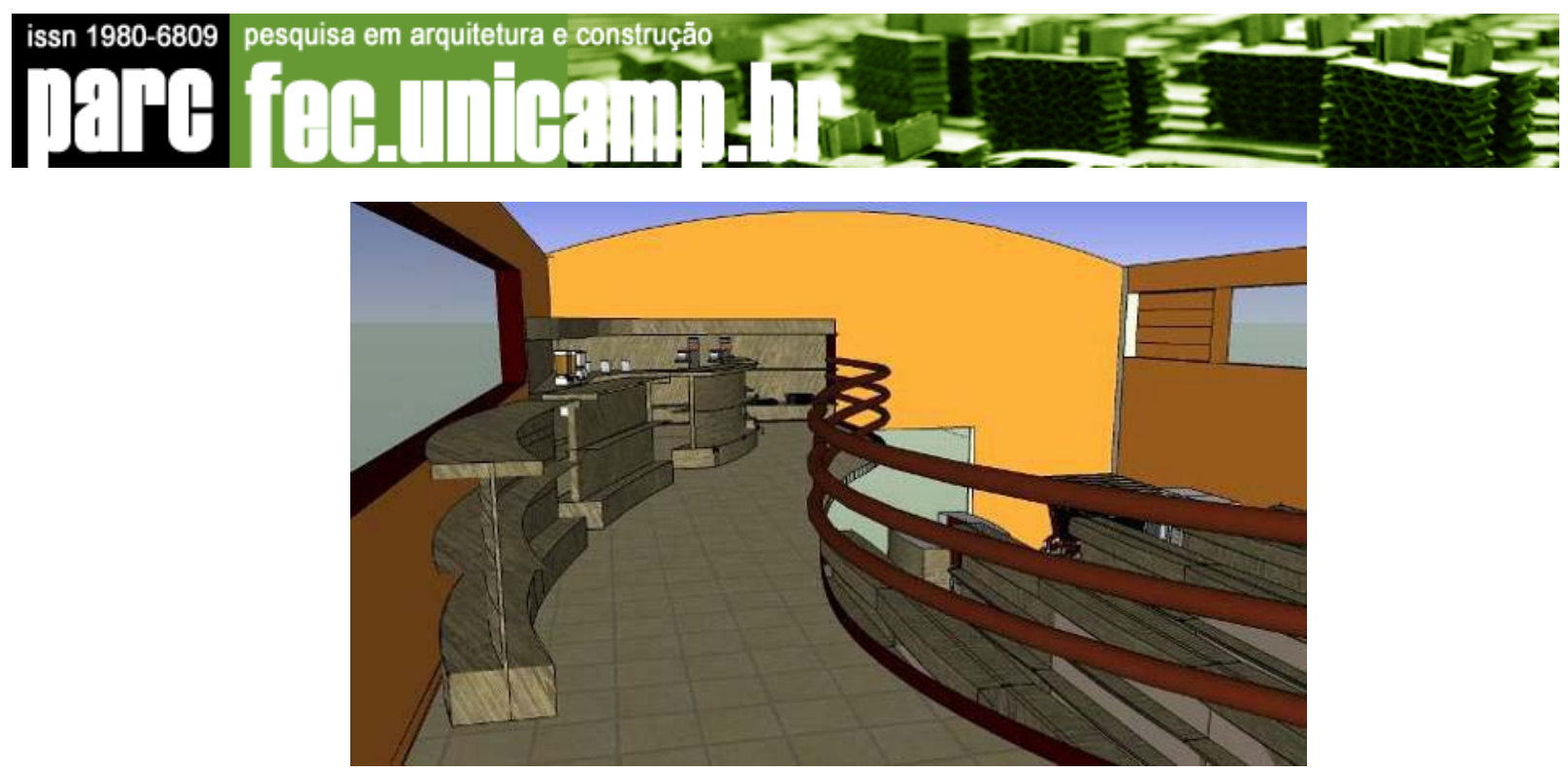

FIGURA 5: Mezanino e gôndolas com forma sinuosa

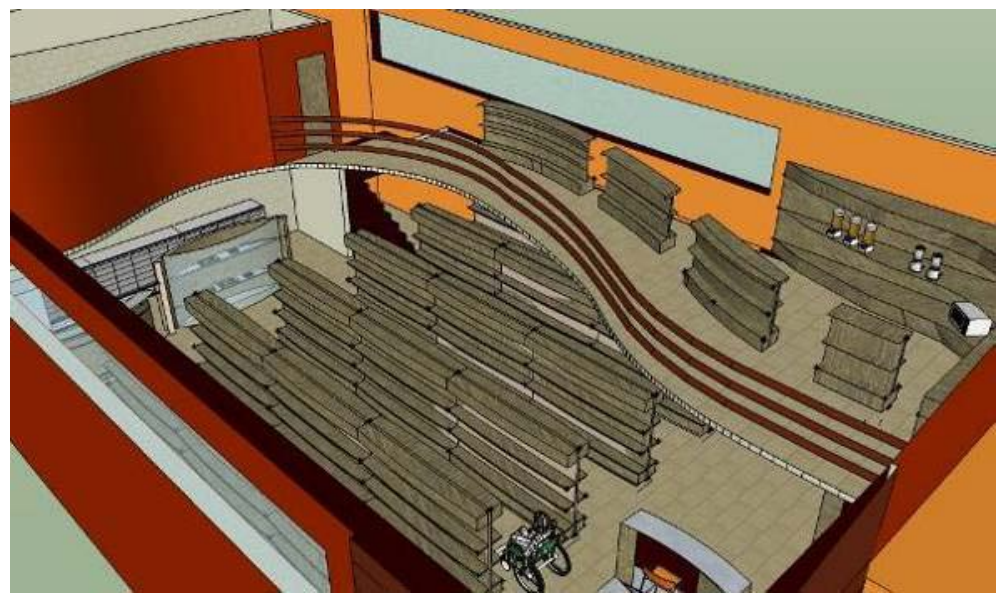

FIGURA 6: Mezanino e gôndolas com forma sinuosa

A opção do mezanino surgiu devido à falta de espaço para acomodar as mercadorias em um único pavimento do estabelecimento. Embora não seja a solução ideal, o intuito era organizar o ambiente e ampliar o espaço no pavimento térreo, transferindo os eletroeletrônicos, os materiais escolares e os utensílios domésticos para o pavimento superior. Medida essa um tanto paliativa, pois o ideal seria que houvesse espaço para a ampliação da área do supermercado.

Ainda no pavimento superior, o depósito já existente, conforme mostra a FIG. 7 aderiu à forma sinuosa estabelecida pelo mezanino e conseqüentemente o açougue que se encontra no pavimento térreo, abaixo do depósito, adquiriu a mesma forma. Esta proposta aperfeiçoou o espaço do açougue que originalmente apresenta menores dimensões. 

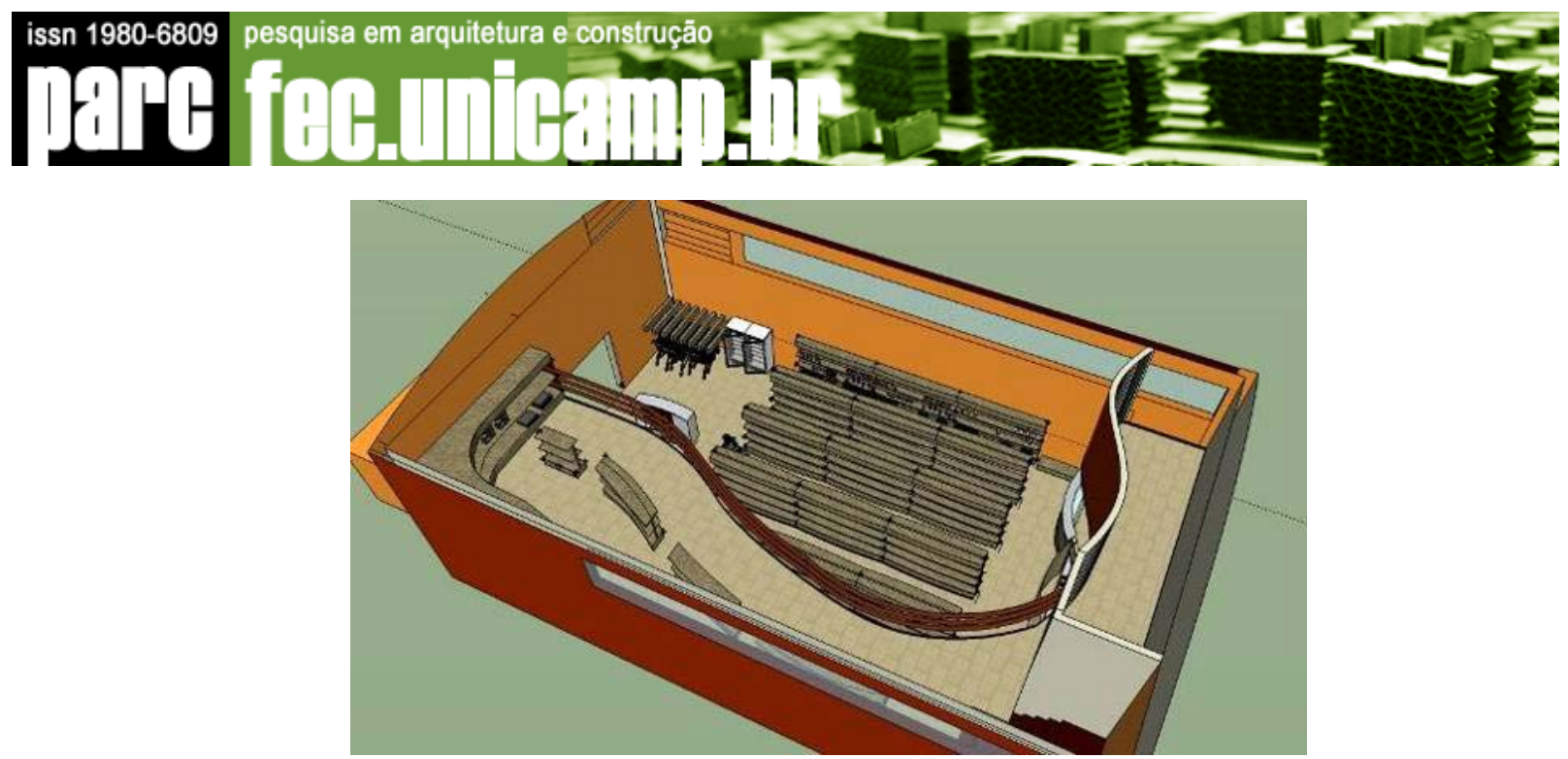

FIGURA 7: Perspectiva do mezanino e depósito

Como o espaço do supermercado não comportaria a quantidade de produtos que o proprietário desejava armazenar, deixou-se de inserir alguns elementos, como uma plataforma de elevação (veja http://www.dwa.eng.br/plataforma.html>), que daria acesso ao mezanino, permitindo a acessibilidade de todos os clientes, principalmente deficientes físicos ou pessoas com mobilidade reduzida. Sua implantação ocuparia o espaço do açougue e impediria a construção da escada em casos de emergências. O mesmo problema foi encontrado em relação às dimensões da copa e do banheiro; não havendo espaço para ampliá-los, decidiu-se mantê-los para o uso exclusivo de funcionários. Se considerássemos todos os itens estabelecidos pela NBR 9050 (ABNT, 2004) não seria possível garantir a acessibilidade no pavimento térreo para todas as pessoas com mobilidade limitada ou não, uma vez que, neste espaço localizam-se os produtos de grande rotatividade. Portanto, a circulação nos corredores do supermercado, observada nas FIG. 8A e 8B, foi dimensionada de acordo com as medidas padrões para a passagem de um cadeirante. Cabe ressaltar que o projeto assegura o acesso de cadeirantes e pessoas com mobilidade reduzida, não priorizando deficientes visuais e crianças. 


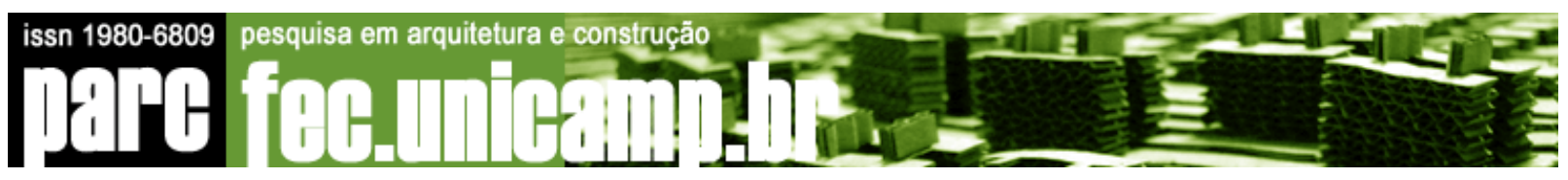

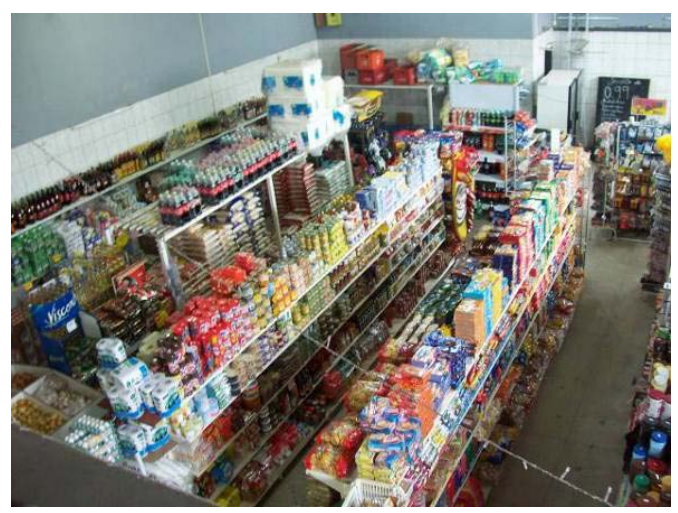

A

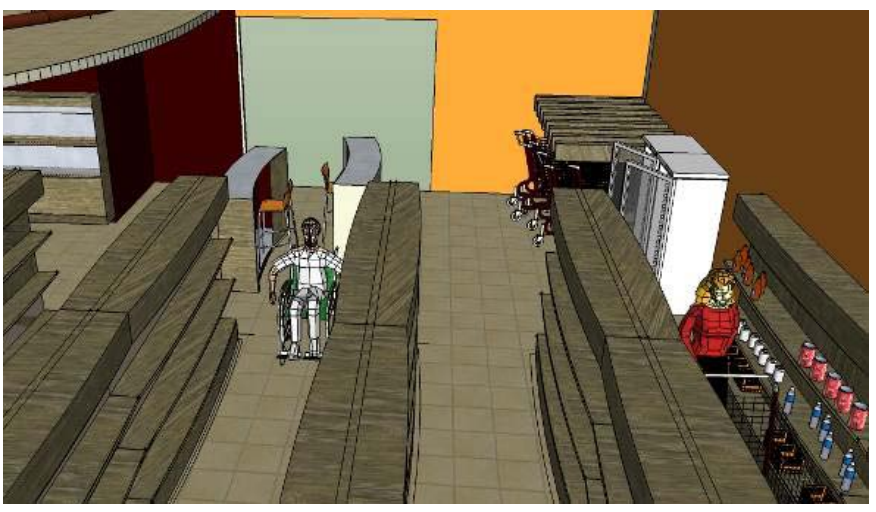

B

FIGURA 8: Corredores originais (A) e proposta (B)

A escada original, ilustrada na FIG. 9, foi redimensionada, ou seja, calculada novamente, pois estava fora das medidas mínimas e por dificultar o fluxo de pessoas ao mezanino garantindo acesso adequado ao pavimento superior por pessoas sem deficiência ou mobilidade reduzida.

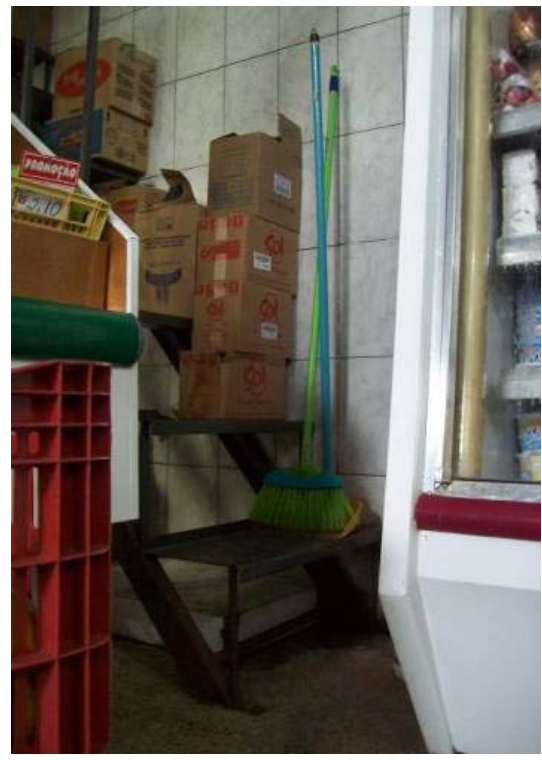

A

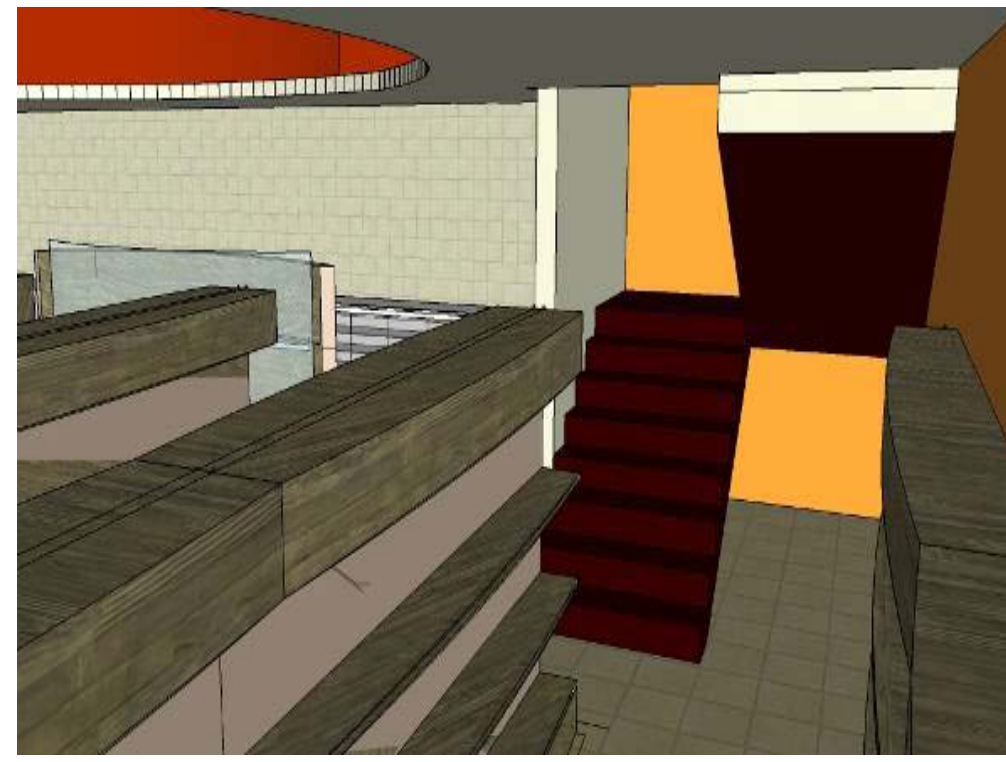

B

FIGURA 9: Escada original (A) e proposta (B)

O fluxo de pessoas foi devidamente estudado de maneira a separar os clientes que entram no estabelecimento dos que saem, conforme a FIG. 10. Duplicou-se o pé direito desta área de acesso criando a sensação de amplitude do espaço, como mostram as FIG. 11A e 11B. Como conseqüência, criou-se aberturas altas na lateral direita do estabelecimento para 


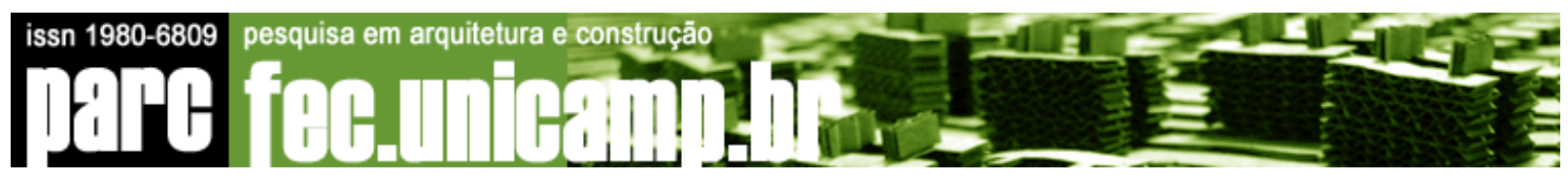

permitir a ventilação cruzada, melhorando a térmica e a luminosidade no interior do edifício, pois segundo Gurgel (2005), o espaço de trabalho deve ser um local confortável com boa iluminação, conforto e ventilação. O projeto de design de interiores pode ser observado nas FIG. 12 e 13.
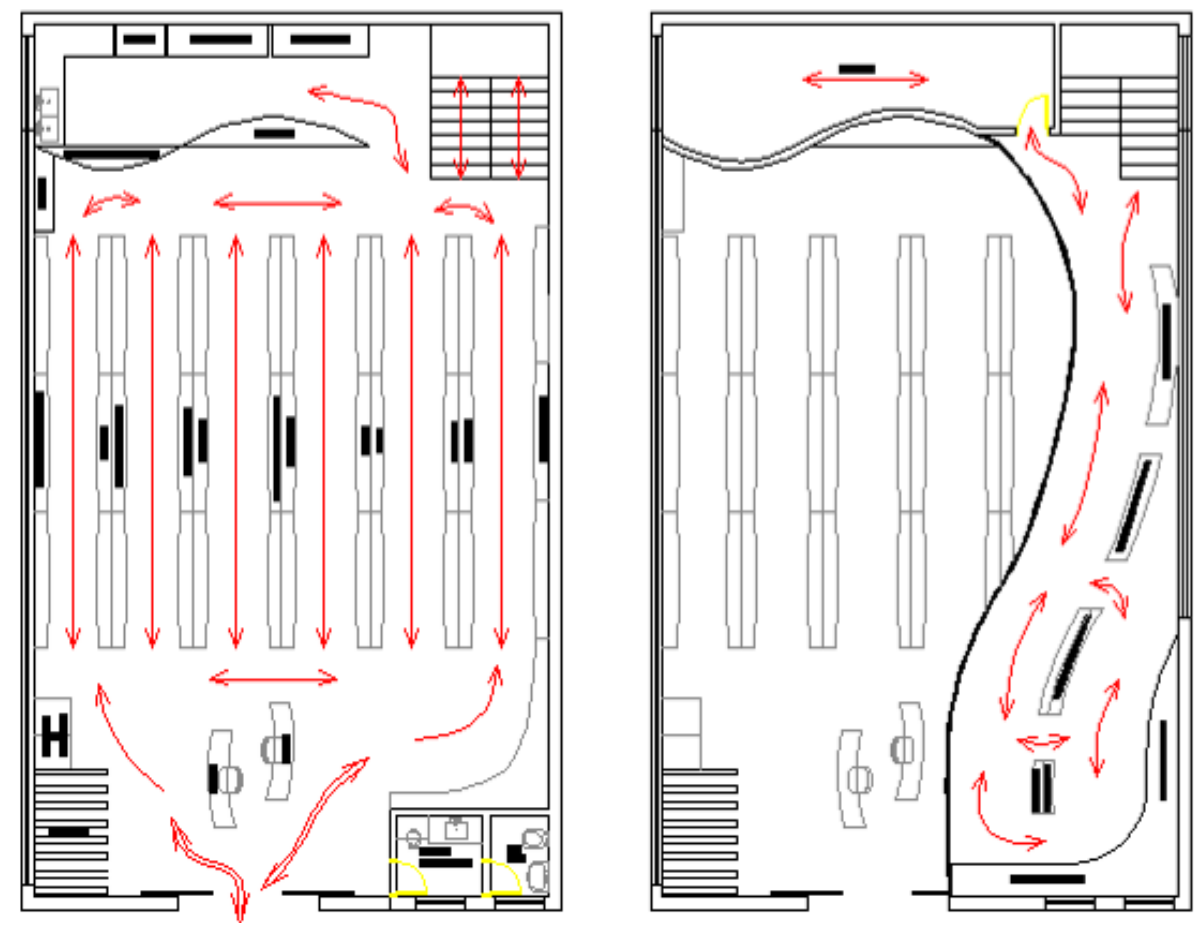

FIGURA 10: Fluxograma do pavimento térreo e mezanino

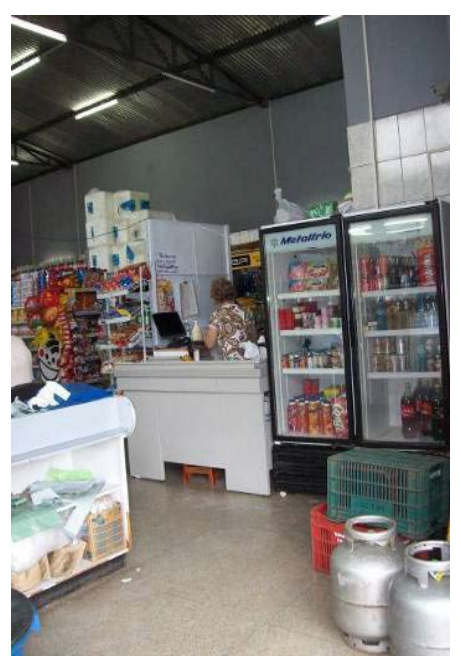

A

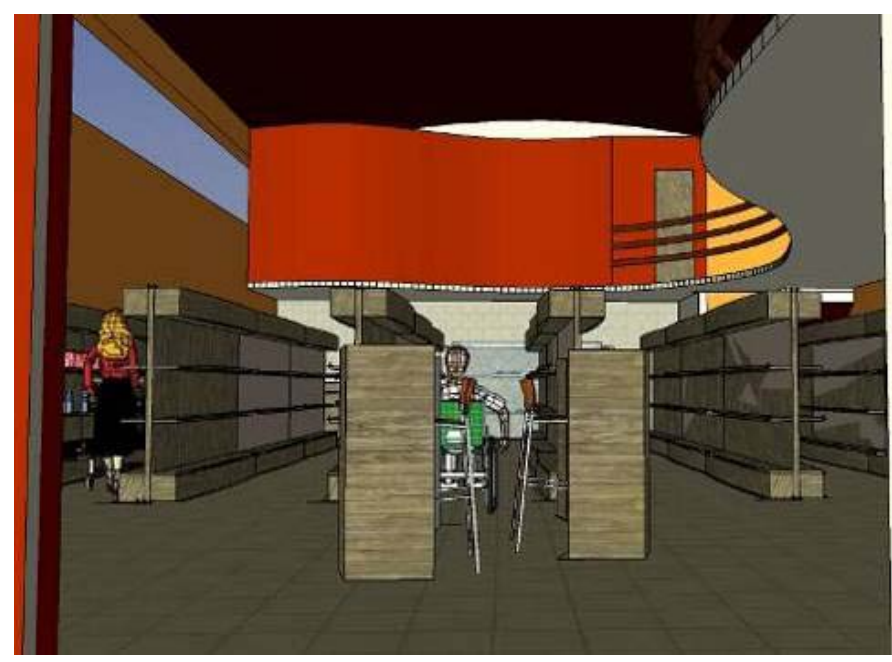

B

FIGURA 11: Acesso principal original(A) e proposta (B) 

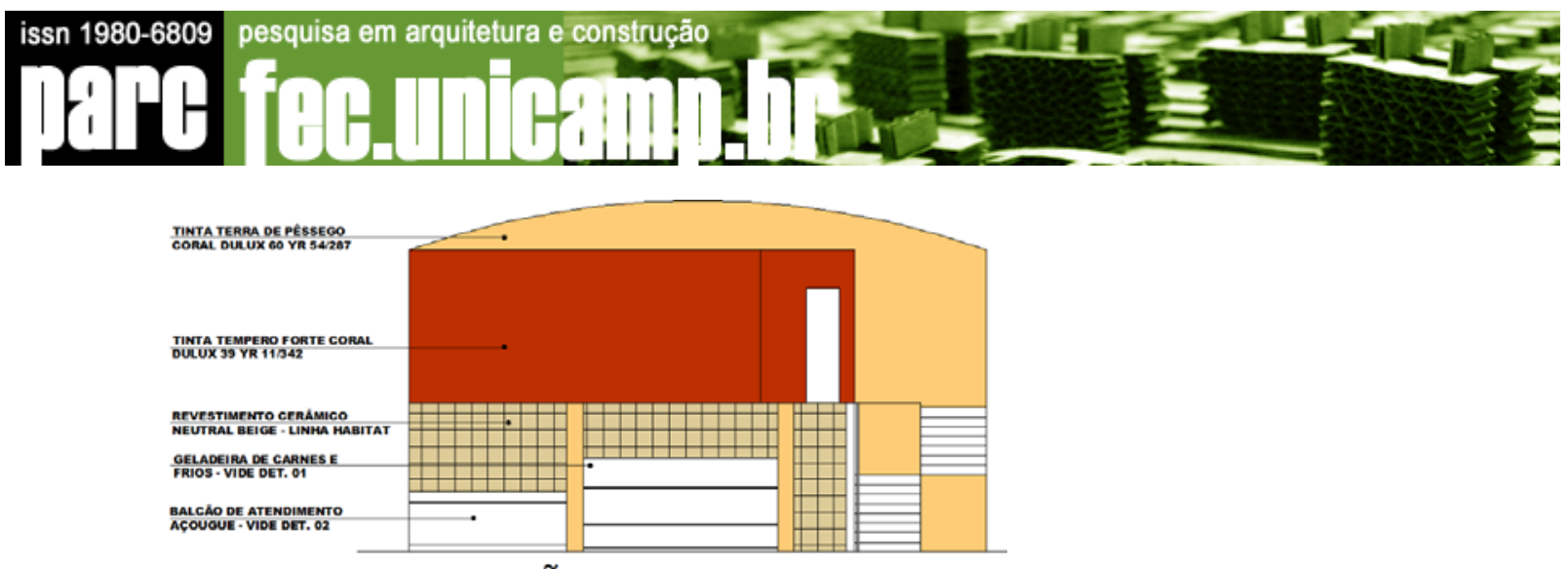

ELEVAÇÃO 1
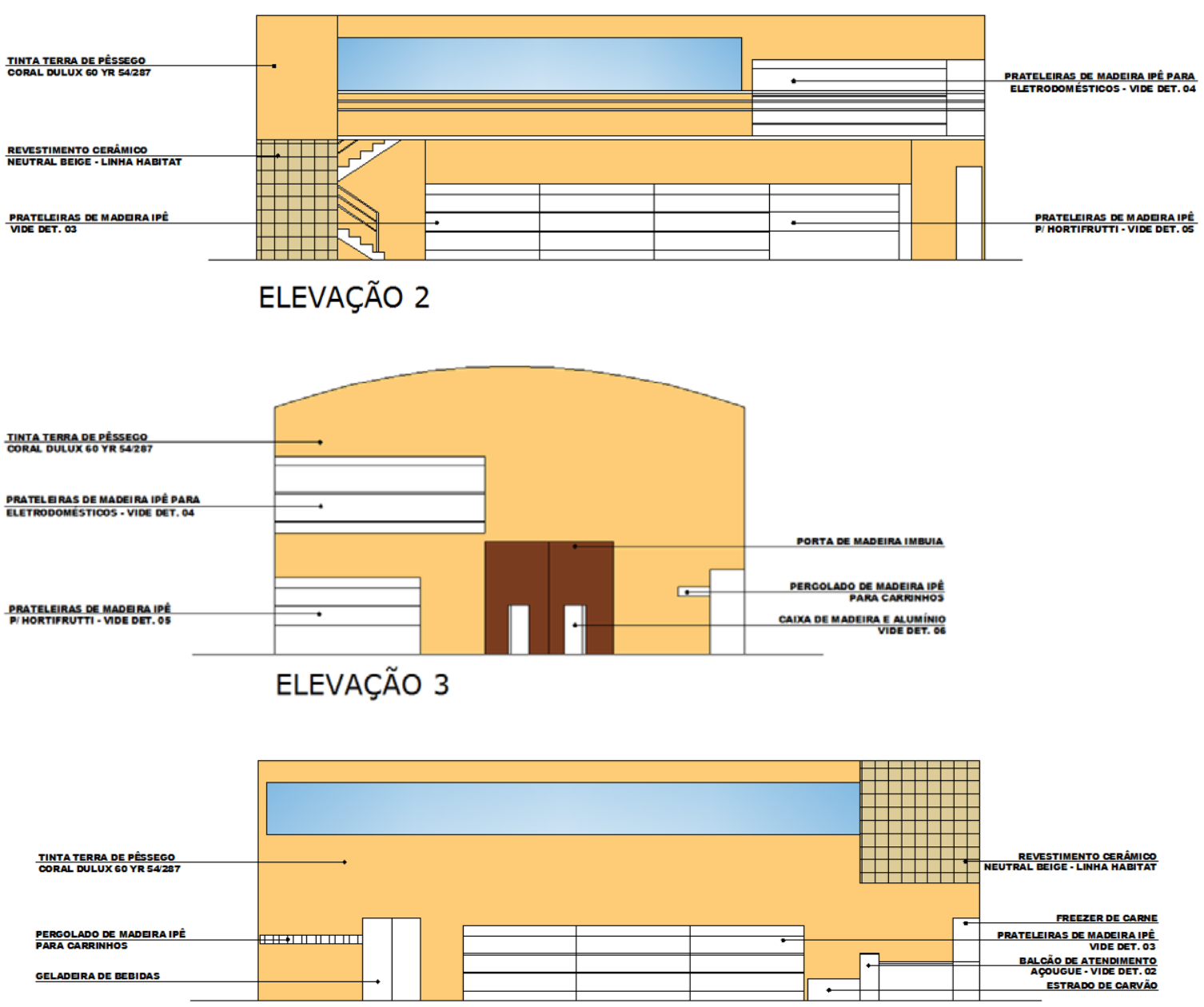

ELEVAÇÃO 4

FIGURA 12: Elevações do projeto 

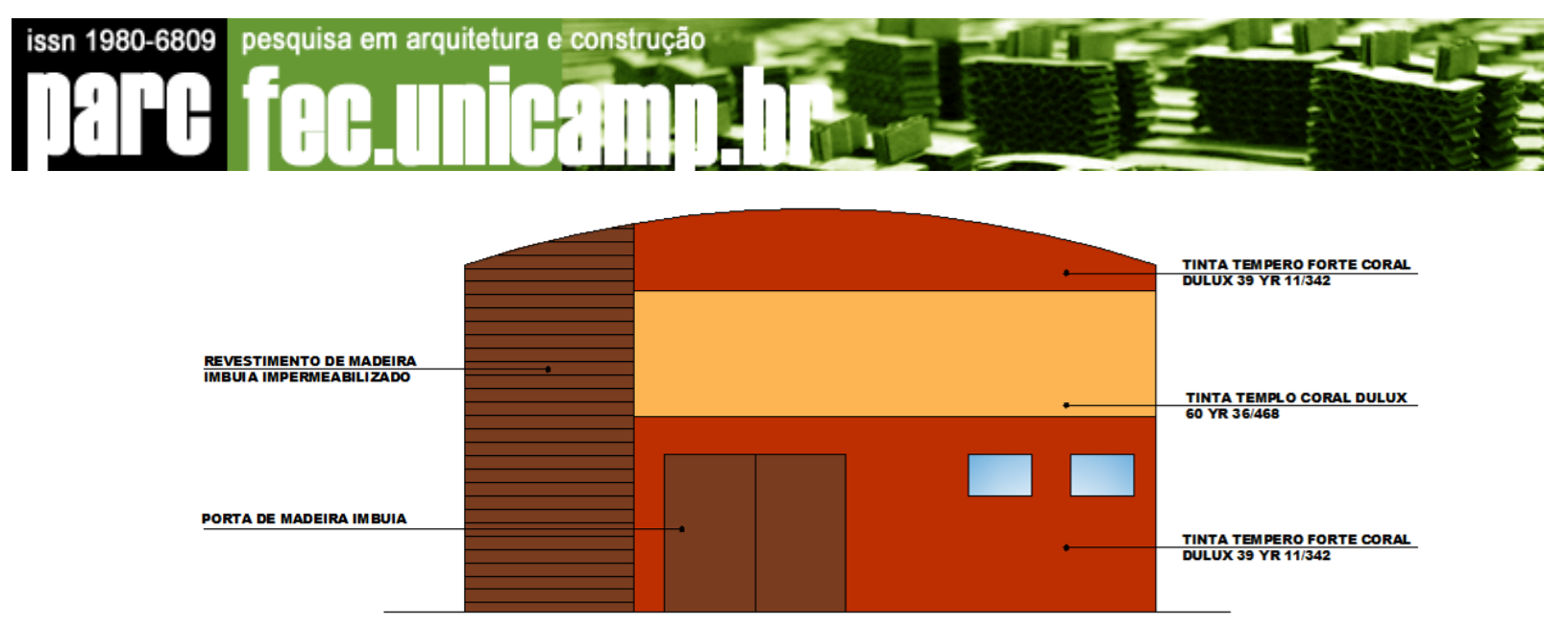

FACHADA PRINCIPAL

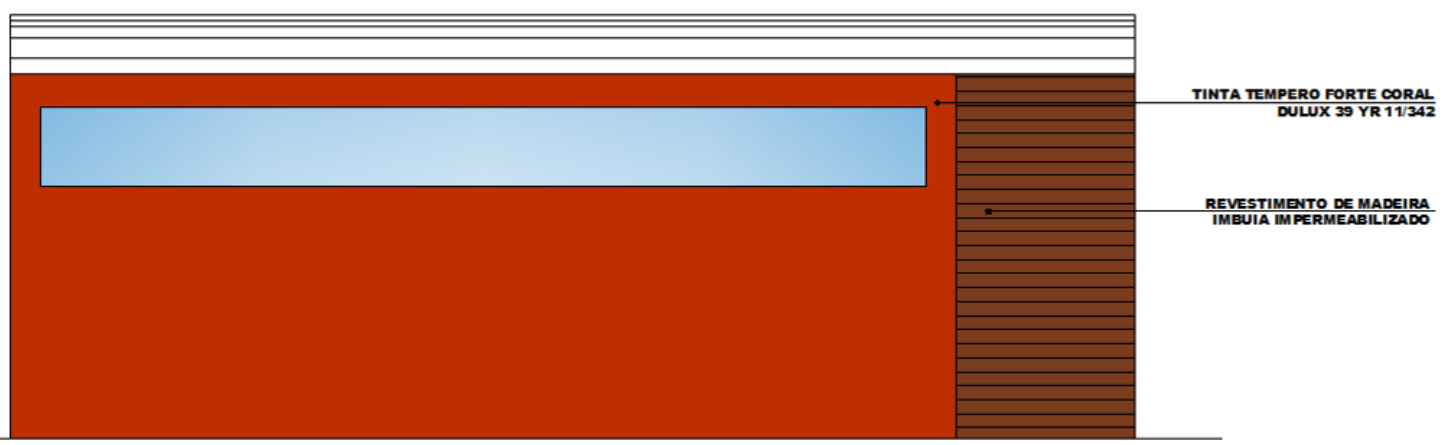

FACHADA LATERAL ESQUERDA

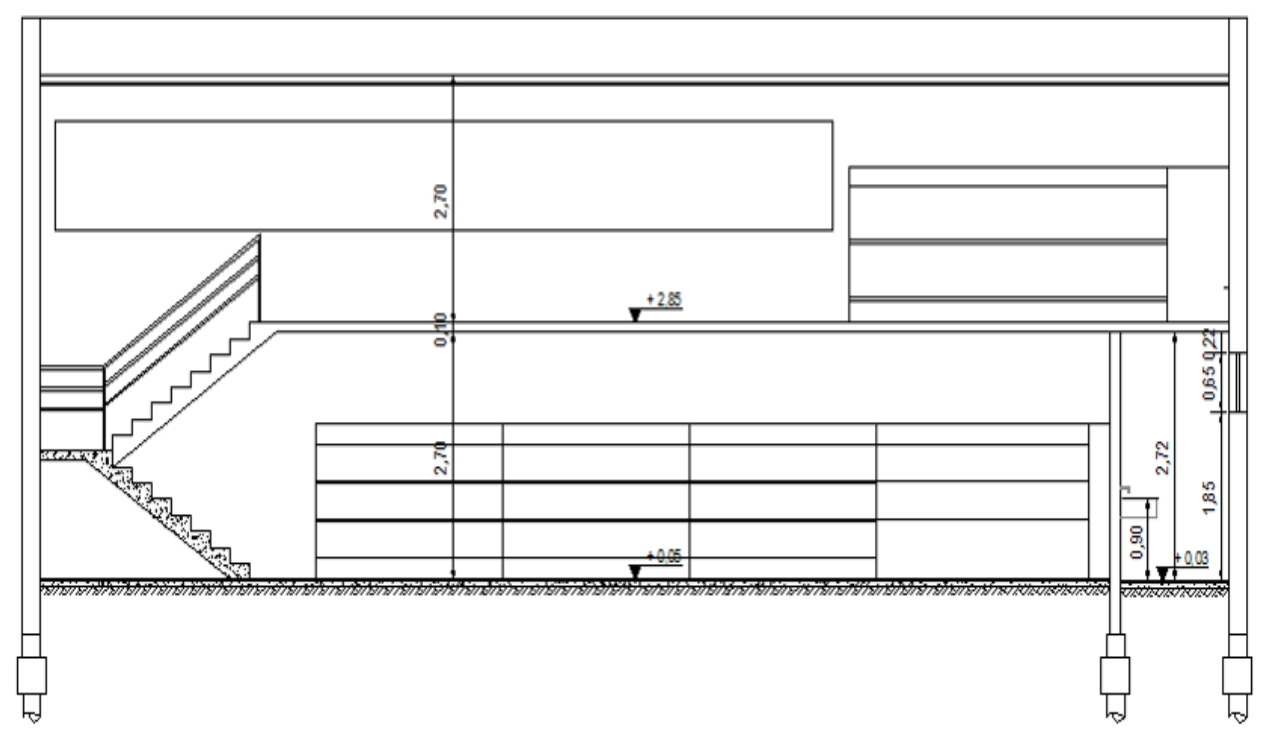

$\mathrm{AA}$

FIGURA 13: Fachadas e corte do projeto 
A iluminação artificial foi projetada com o objetivo de provocar um efeito homogêneo em toda a superfície do supermercado, exceto nas regiões dos caixas e açougue. Para aperfeiçoar a iluminação nessas áreas, foram embutidas luminárias pendentes próximas a área de trabalho.

Dentre as decisões operacionais correntes na atividade varejista, são fundamentais as relacionadas ao layout interno do supermercado, mais especificamente à disposição dos produtos. Frente às limitações de espaço interno, o arranjo encontrado para a distribuição dos produtos não somente vai influenciar diretamente as vendas de cada loja, como também significa um componente importante da estrutura de custos do supermercado. A localização das seções e o "caminho" traçado para o percurso do consumidor são decisões estratégicas para o sucesso do negócio. (CESARINO \& CAIXETA, 2002, p. 2)

\section{Considerações Finais}

A acessibilidade garante que os espaços públicos e privados sejam acessados por todos, promovendo a inclusão social.

O design de interiores contribui para que as pessoas tenham acesso à ambientes com qualidade e estética, proporcionando espaços mais agradáveis para trabalhadores e clientes.

O desenho universal não vê a acessibilidade como um anexo, mas entende que o desenho do meio é capaz de torná-lo mais eficiente, produtivo, confortável, legível e seguro, em graus equivalentes a todas as pessoas, neste projeto a melhoria do espaço foi alcançada. O espaço construído não pode ser adaptado ou projetado de forma categorial, ou seja, tratando os deficientes como minoria e como pessoas que necessitam de equipamentos especiais, como banheiros separados, entradas secundárias, locais reservados para idosos. Foi pensado um meio de maneira mais integrada, levando em conta todos os usuários, a evolução do processo de utilização do espaço, sua adaptabilidade a possíveis mudanças e sua capacidade de interação.

A análise apresentada conclui que os problemas existentes foram analisados e questionados, criando um ambiente mais acessível, confortável e esteticamente agradável.

O ideal, como proposta, seria que o supermercado aumentasse sua área construída em pelo menos $75 \mathrm{~m}^{2}$, com aquisição de algum dos lotes de divisa, para atender todas as exigências discorridas na norma de acessibilidade, como a construção de banheiros e lavabos para clientes e funcionários e implantação de uma plataforma de elevação para acesso ao mezanino. Com esta ampliação, o projeto poderia também adequar-se na área de 
ergonomia, nas questões da usabilidade e de funcionalidade, melhorando o conforto do espaço para funcionários e clientes.

Deste modo, o projeto priorizou o design de interiores abordando aspectos fundamentais do desenho universal, tais como a largura adequada dos corredores e o acesso principal através da divisão dos fluxos de entrada e saída do estabelecimento. O resultado do design de interiores foi satisfatório, uma vez que, atendeu às exigências do proprietário, adequando-se às características locais, tornando o espaço mais agradável aos consumidores e principalmente aos funcionários, que permanecem por um longo período no local.

Cabe lembrar que, embora esta problemática englobe todos os usuários dos espaços públicos, os sintomas são mais prejudiciais aos cadeirantes ou pessoas com mobilidade reduzida, por não terem espaços adaptados às suas características de deslocamento, têm a mobilidade restrita, pouca chance de se socializar e ficam impossibilitados de realizar as atividades que the seriam possíveis, porque os locais públicos não são concebidos de maneira mais inclusiva.

Portanto, construir sem barreiras ou projetar sem barreiras é um conceito que deve dar respostas às necessidades de todos os cidadãos que tenham ou não qualquer tipo de deficiência, não deixando de lado a evolução no processo de utilização do meio físico. Para que no futuro se possa reconhecer a acessibilidade de todos os espaços, deve-se de imediato implantar um procedimento projetual, impedindo o surgimento de novos ambientes inacessíveis e a definição de uma estratégia que promova as adaptações necessárias aos espaços existentes, de forma gradativa.

\section{Referências}

ALVES, Antonio Pedro. Entenda os diversos formatos de varejo. Disponível em: <http://www.vendamuitomais.com.br/site/artigo.asp?ld=126>. Acesso em: 30 mar. 2010.

ARANHA, M.S.F. Inclusão social e municipalização. In: MANZINI, E.J. Educação Especial: Temas Atuais. Marília: Unesp- Publicações, 2000. 9p. Disponível em:<cape.edunet.sp.gov.br/ textos/textos/10.doc>. Acesso em: 14 ago. 2010.

ASSOCIAÇÃO BRASILEIRA DE NORMAS TÉCNICAS. Norma NBR 9050 - Acessibilidade de pessoas com deficiência a edificações, espaço, mobiliário e equipamentos urbanos. Rio de Janeiro, 2004. 97 p.

BRASIL. Decreto $\mathbf{n}^{\circ} 3.298$ - Estatuto das Pessoas com Deficiência. Disponível em: http://www.camarpho.hpg.ig.com.br/Leis/estatutodeficiente.htm>. Acesso em: 09 abr. 2010 
BRASIL. Decreto n. 37.649 - de 25 de setembro 1998. Regulamenta as Leis $n^{0}$. 11.345, de 14 de abril de 1993, e $n^{\circ}$. 11.424, de 30 de setembro de 1993, que dispõem sobre exigências relativas à adaptação das edificações à pessoa com deficiência física ou mobilidade reduzida, e dá outras providências. 5 p.

CAMBIAGHI, Silvana. Desenho Universal: métodos e técnicas para arquitetos e urbanistas. São Paulo: Editora SENAC São Paulo, 2007. 269 p.

CARLETTO, Ana Claudia; CAMBIAGHI, Silvana. Desenho Universal: um conceito para todos. (Realização Mara Gabrilli). São Paulo, 2008. Disponível em: <http://vereadora maragabrilli.com.br/files/universal_web.pdf>. Acesso em: 05 out. 2009. 38 p.

CESARINO, Rodrigo Coltelli; CAIXETA FILHO, José Vicente. Alocação dos produtos nas gôndolas dos supermercados: um estudo de caso. Disponível em: <http://www.scielo.com .br/scielo.php?script=sci arttext\&pid=S0104530X2002000100005. Acesso em 31 mar. 2010. $25 \mathrm{p}$.

COMISSÃO PERMANENTE DE ACESSIBILIDADE. Secretaria Especial da Pessoa com Deficiência e Mobilidade Reduzida. Prefeitura de São Paulo. Guia de mobilidade acessível na cidade de São Paulo. São Paulo, 2005. Disponível em:<http://wwwp.feb.unesp.br/lutt/ Acessibilidade/acessibilidade_sp.pdf>. Acesso em: 31 mar. 2010. 167 p.

GURGEL, Miriam. Projetando espaços: design de interiores. São Paulo: Editora Senac São Paulo, 2007. 224 p.

Projetando espaços: guia de arquitetura de interiores para áreas comerciais. São Paulo: Editora Senac São Paulo, 2005. 224 p.

Projetando espaços: guia de arquitetura de interiores para áreas residenciais. São Paulo: Editora Senac São Paulo, 2005. 301 p.

LUCIANÓPOLIS. Lucianópolis. Disponível em: <http://www.seade.gov.br/produtos/iprs/anali ses/Lucianopolis.pdf>. Acesso em: 01 abr. 2010. 2 p.

MANCUSO, Clarice. Guia prático do design de interiores. Porto Alegre: Editora Sulina, 2008. $173 \mathrm{p}$.

MORO, Marcelo. Supermercados no Brasil. 2007. Disponível em: <http://acasadomarcelo. blogspot.com/2007/05/21-supermercados-no-brasil.html>. Acesso em: 30 mar. 2010.

ORNSTEIN, Sheila Walbe. Apresentação. In: CAMBIAGHI, Silvana. Desenho Universal: métodos e técnicas para arquitetos e urbanistas. São Paulo: Editora SENAC São Paulo, 2007. 269 p.

PAULA Ana Rita de; BUENO, Carmem Leite Ribeiro. Acessibilidade no mundo do trabalho. (S.1 :s.n.), 2004. Disponível em:<http://www.sorri.com.br/artigos/Acessibilidade NoMundoDoTrabalho.pdf>. Acesso em 08 abr. 2010. 4 p. 


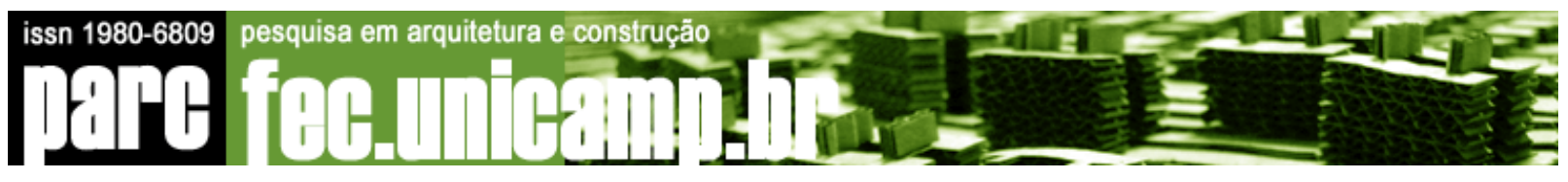

PRADO, Adriana Romeiro de Almeida. Acessibilidade e desenho universal. Disponível em: < http://direitodoidoso.braslink.com/pdf/acessibilidade.pdf>. Acesso em 09 de abr. 2010. 10 p.

SECRETARIA DE ESTADO DA HABITAÇÃO. Secretaria de Estado dos Direitos da Pessoa com Deficiência e Companhia de Desenvolvimento Habitacional e Urbano. Governo do Estado de São Paulo. Desenho universal, habitação de interesse social. São Paulo: Governo do Estado de São Paulo, 2010. Disponível em: <http://www.iabsp.org.br/ Desenho_Universal-Manual_de_Diretrizes_Aplicacao.pdf>. Acesso em 31 mar. 2010. 97 p.

WRIGHT, Charles L. (Edit.). Facilitando o transporte para todos. Washington, D.C. : Banco Interamericano de Desenvolvimento, $1^{\text {a }}$ ed., 2001. Disponível em:<http://books.google. com.br/> Acesso em 08 abr. 2010. 65 p.

\section{Notas:}

\footnotetext{
i Tratado de Vitrúvio, ao ser redescoberto no Renascimento, tornou-se o texto fundador de um entendimento moderno da arquitetura e da construção. Arquiteto e engenheiro romano Marco Vitrúvio Polião, escrito no século I da nossa era. Fonte: http://istpress.ist.utl.pt/lvitruvio.html.

ii Charles-Edouard Jeanneret, conhecido por Le Corbusier, nasceu a 6 de Outubro de 1887 em La Chaux-de-Fonds, Suíça, mas viveu a maior parte da sua vida em França. Foi um arquiteto que constituiu um marco muito importante no desenvolvimento da arquitetura moderna. Fonte: http://www.educ.fc.ul.pt/icm/icm2000/icm33/Corbusier.htm.

iii Gestalt tem o significado de uma entidade concreta, individual e característica, que existe como algo destacado e que tem uma forma ou configuração como um de seus atributos. Fonte: http://www.igestalt.psc.br/gestalt.htm.
} 